\title{
Juridical Analysis of Criminal Law Enforcement on the Criminal Acts of Online Business Fraud
}

\author{
Yuhernawa $^{1}$, Zudan Arief Fakrulloh ${ }^{2}$ \\ University of Borobudor ${ }^{1,2}$ \\ \{yuhernawaunboro@gmail.com ${ }^{1}$, cclsis@yahoo.com ${ }^{2}$ \}
}

\begin{abstract}
In the current era, internet access is an inseparable need from the life of the digital society. The advancement of communication technology is even used by the community to make it easier for the business to be carried out. This convenience also seems to be used by irresponsible parties who use this opportunity for things that are detrimental to others. Fraud in the name of an online business is widely practiced and often makes many people tempted by the offers of conveniences that are provided. This pandemic period was used as an opportunity for actors to offer goods at low prices but did not guarantee quality or even fictitious businesses. If this continues, it will be very detrimental to consumers. Seeing this phenomenon, it is necessary to enforce criminal law against criminal acts of online business fraud. This study uses a normative juridical approach. Collecting data using analysis and study of literature sources which are then analyzed and presented in the form of descriptive exposure. The results showed that criminal law enforcement against criminal acts of online business fraud is subject to Article 378 of the Criminal Code, Article 28 paragraph (1) and Article 45 paragraph (2) of Law Number 11 Year 2008 concerning Electronic Information and Transactions.
\end{abstract}

Keywords: Law Enforcement; Crime; Online Business

\section{Introduction}

Advances in information and communication technology make it easier for people to receive and provide information to the wider community. The conveniences that can be enjoyed through internet access are online learning, working online, to online business. Technological developments are not only for the sake of establishing communication but opening the eyes of the world to a new world, new interactions, new market places, and a world-wide business network. The development of technology called the internet, has changed the pattern of community interaction, in the fields of science, business, economy, social and culture. The presence of the internet has supported the effectiveness and efficiency of the company's operations, especially its role as a means of communication,

This technological advancement also seems to be an opportunity for irresponsible parties. They take advantage of this opportunity to get profit through online business scams. Online business is a business that is conducted via the internet as a marketing medium using a website as a catalog. Online business has become a trend and is also an opportunity for irresponsible 
parties to commit a crime that causes harm to others [1]. For the sake of getting profit and enriching themselves, the perpetrators violate the rules and norms of the applicable law. Online businesses make it easier for fraudsters to carry out their actions.

Sales are the most important transactions in business or commercial activities. Basic human needs in the form of food, clothing and shelter can be found easily through online purchases. The covid-19 pandemic which limits the mobility and interaction of individuals to gather is a golden opportunity for online investors and entrepreneurs. With easy internet access, buyers can see directly the goods traded in cyberspace, pay for them by bank transfer and only wait a few moments for the goods to arrive.

When the internet has become a necessity for some people, the process of buying and selling via the internet is familiar. The process of buying and selling online is called ecommerce or electronic commerce. Basically, it is part of an electronic business [2]. Currently the position of the internet is not only a consumption for certain groups but has become a necessity for all groups of society in general. Fraud with the mode of selling via the internet lately, claiming to be cheap in the market, has attracted many people to buy it, even though online business fraud has been partially exposed, but the prosecution of individuals against this action has not reached the law. This is because online fraud victims are reluctant to report to law enforcement, while fraud crimes are categorized as ordinary offenses. Law is the whole code of behavior that applies in a common life, which can be enforced with a sanction [3]. Lack of firm and clear law enforcement against perpetrators of online business fraud, often triggers this fraud.

\section{Methodology}

This study uses a normative juridical approach. Collecting data using analysis and study of literature sources which are then analyzed and presented in the form of descriptive exposure.

\section{Result and Discussion}

\subsection{Criminal Law Enforcement}

Law enforcement is the process of making efforts to uphold or function legal norms as a guide for behavior in traffic or legal relations in public and state life. From the point of view of the subject, law enforcement can be carried out by a broad subject and can also be interpreted as an effort to enforce the law involving all subjects. Law enforcement is an effort to bring ideas about justice, legal certainty and social benefits into reality [4]. Criminal law enforcement is an effort to realize ideas about petty in criminal law in legal certainty and social benefits into legal realities in legal certainty and social benefits into legal realities in every legal relationship [5]. Criminal law enforcement consists of two core stages, namely:

\section{a) Criminal Law Enforcement in Abstracto}

Enforcement of criminal law in abstracto is a stage of making / formulating (Formulation Stage) which has ended when a statutory regulation is promulgated. The legislation / formulation stage is continued to the application stage and the execution stage. Criminal law enforcement (PHP) is a part (sub-system) of the entire national law enforcement system / 
policy, which is basically part of the national development system / policy. Criminal law policy (penal policy), both in the sense of PHP in abstracto and in concreto, is part of the overall system policy (enforcement) of the national law and is an effort to support the national development policy (national development policy).

An integral criminal law enforcement system (SPHP) needs to be seen in abstracto (law making and law reform) because PHP in abstracto (making / changing laws, law making / law reform) is a stage of making / formulating (formulating) laws. leh the legislature (can be called the legislative stage). According to Barda nawawi arief, law enforcement in abstracto is carried out through (the process of legislation / formulation / making of statutory regulations) carried out through legislation / formulation / making of statutory regulations [6]. This legislation / formulation process is a very strategic start of an in-concreto law enforcement process.

\section{b) In Concreto Criminal Law Enforcement}

Enforcement of criminal law in concreto consists of: the stage of application / application (investigation) and the stage of implementing laws by law enforcement officials, which can be called the judicial stage and the stage of execution. Enforcement of criminal law in concreto is essentially a process of imposing a crime or a process of punishment. The criminal process itself is a criminal law enforcement process in the context of upholding truth and justice. The two stages are crucial aspects or points of the handling and prosecution of a criminal case. Law enforcement is an effort made to make law, both in a narrow formal sense and a broad material meaning, as a code of conduct in every legal action [7].

Based on the foregoing, it can be said that the function of law enforcement is to actualize legal rules so that they are in accordance with what the law itself aspires to, namely realizing human attitudes or behavior in accordance with the frame (frame work) established by a law. statute or law. To enforce criminal law, it must go through several stages which are seen as a rational effort or process that is deliberately planned to achieve a certain goal which is a link in a chain of activities that does not include values and leads to crime and conviction [8]. These stages are:

1. Formulation Stage: the stage of criminal law enforcement in abstracto by a law-making body that carries out the activity of selecting values according to current and future circumstances and situations, then formulating them in the form of legislation that best meets the requirements justice and efficiency. This stage is called the legislative policy stage.

2. Application Stage: the stage of criminal law enforcement (criminal law enforcement stage) by law enforcement officials, starting from the police to the court or examination before a trial. Thus, law enforcement officers are tasked with enforcing and implementing laws and regulations that have been made by lawmakers. In carrying out this task, law enforcement officers must adhere to the values of justice and efficiency. This stage is called the judicative stage.

3. Execution Stage: the stage of law enforcement (law enforcement) in a concrete manner by the criminal executing apparatus. At this stage, the criminal law enforcement apparatus is tasked with enforcing the laws and regulations that have been made by the legislative bodies through the application of penalties determined by the court. In carrying out their duties, the criminal apparatus must be guided by the criminal laws and regulations that have been made by the legislators and the value of use and justice. 


\subsection{Overview of the Crime of Fraud}

The act of fraud is an act that is detrimental to other people so that it is an act that can be subject to criminal law. In this case, fraudulent acts through online businesses have several forms, both in the form of lies or in the form of actions with the intention of seeking their own profit from others. The benefits in question are either in the form of material benefits or benefits that are abstract in nature, for example removing someone from their position.

In the KUHP, to be precise, Article 378 of the Criminal Code stipulates the crime of fraud in a general form, while those listed in Chapter XXV of Book II of the Criminal Code contain various forms of fraud against property formulated in several articles, each of which has special names. All articles in Chapter XXV are known as bedrog or people's actions. The crime of fraud (bedrog) is contained in Chapter XXV of Book II of the Criminal Code, from Article 378 to Article 349. The original title of this chapter is bedrog which has been widely translated as fraud, or some have translated it as an act of people. The word fraud itself has two meanings, namely [9]:

a. Fraud in a broad sense, namely all crimes defined in Chapter XXV of the Criminal Code.

b. Fraud in the narrow sense, is a form of fraud formulated in Article 378 of the Criminal Code (main form) and Article 379 of the Criminal Code (special form). In Article 378 of the Criminal Code which regulates the following; "Anyone who with the intention of wanting to benefit himself or others by fighting rights, either by using a false name, either by action and deception or with fabrications of lies, persuades people to give something, incurs a debt or writes off a debt, is threatened. for fraud with a maximum imprisonment of four years".

\subsection{Online Business as a Form of Cybercrime}

Cybercrime is a crime committed using computer technology as the main crime tool. Cybercrime is a crime that takes advantage of the development of computer technology, especially the internet.[10] Cybercrime is defined as an illegal act that utilizes computer technology based on the sophistication of internet technology development.[11] In online business fraud is categorized as cyber crime. To ensnare the perpetrator with criminal law, it is not sufficient to study criminal law with Article 378 of the Criminal Code because the sentence is too light and does not cause a deterrent effect. Because it is related to the misuse of ITE, Article 28 paragraph (1) and Article 45 paragraph (2) of Law Number 11 Year 2008 concerning Electronic Information and Transactions may apply.

\section{Conclusion}

The rapid development of science and technology is always accompanied by the development of more sophisticated and advanced crimes or crimes. This is indicated by the rapid development of how to commit crimes (modus operandi) and the tools it uses. Therefore, it is necessary to know more about this online business fraud crime and what regulations are used for efforts to overcome it by law enforcement officials. The government and law enforcement officials should for cases of online business fraud be imposed using Article 28 paragraph (1) and Article 45 paragraph (2) Law Number 11 Year 2008 concerning Electronic Information and Transactions. It is necessary to increase understanding and performance among law enforcement officials in preventing criminal acts of online business fraud. The 
active role of the government and law enforcement officials in educating the public about the ins and outs and dangers of online business is also very much needed. If this is not realized immediately, then the fraud mode under the guise of online business will always occur and cause many victims.

\section{References}

[1] Abdul Wahidi and M. Labib, Mayantara crime (cybercrime). Bandung: Refika Aditama, 2005.

[2] N. Suparni, Cyberspace Problematics \& Anticipation of Its Arrangements. Jakarta: Sinar Grafika, 2009.

[3] Andi Hamzah, Indonesian Criminal Procedure Code. Jakarta: Grafika Indah, 1996.

[4] Satjipto Rahardjo, Law Enforcement Issues. Bandung: Sinar Baru, 1987.

[5] Peter Mahmud and Marzuki, Introduction to Legal Studies. Jakarta: Kencana Prenada, 2012.

[6] Barda Nawawi Arief, Criminal Law Policy. Bandung: PT. Citra Aditya Bhakti, 2002.

[7] F. zainal Abidin, Principles of Criminal Law. Jakarta: Sinar Grafika, 2007.

[8] Andi Hamzah, Criminal Law Enforcement Issues. Jakarta: Grafika Indah, 1994.

[9] "The Criminal Code (KUHP)." .

[10] J. Sitompul, Cyberspace, Cybercrimes, Cyberlaw: An Overview of the Aspects of Criminal Law. Jakarta: Rajawali Pers, 2012.

[11] Niniek Suparni, Cyberspace Problematics \& Anticipation of Its Arrangements. Jakarta: Sinar Grafika, 2009. 